\title{
On the Educational Potential of Humor, Science Fiction, and Game
}

\section{Tatiana A. Balakireva (a) \& Mariia N. Mogilevich (b)}

(a) Saint Petersburg State University. Saint Petersburg, Russia. Email: balakireva_tanya[at]mail.ru

(b) ITMO University. St. Petersburg, Russia. Email: maria.mogilevich[at]gmail.com

\begin{abstract}
The modern cultural situation contributes to the rethinking of many areas of human activity that once seemed basic. This is how the image of education which in European culture is traditionally associated with the discipline of mind and will and therefore with extreme seriousness has been changing dramatically. The possibility of such an approach was closely related to the value of knowledge which was once unconditional. However, modern media sources which made knowledge accessible and the patterns of obtaining it ordinary have removed the educational sphere from its common position. Today we see how education is reforming its own aims and objectives and what new methods it attracts in order to keep being an integral part of the personality development in culture. In this article, we will consider one of the aspects of the transformation of education, specifically, the search for new motives for learning. Our goal will be to characterize the educational potential of mechanics drawn from areas such as humor, fiction, and play. All the three phenomena are traditionally perceived rather as part of an entertaining, "not serious" sphere of human activity. We will try to prove their effectiveness in relation to new challenges in the educational area that are generated by the era of new media technologies.
\end{abstract}

\section{Keywords}

Educational Methods; New Educational Technologies; Experience; Involvement; Humor; Science Fiction; Gamification; Game; Motivation; Seriousness

This work is licensed under a Creative Commons «Attribution» 4.0 International License 


\section{Об образовательном потенциале юмора, научной фантастики и игры}

\section{Балакирева Татьяна Андреевна (a), Могилевич Мария Николаевна (b)}

(а) Санкт-Петербургский государственный университет. Санкт-Петербург, Россия. Email: balakireva_tanya[at]mail.ru

(b) Национальный исследовательский университет информационных технологий, механики и оптики. Санкт-Петербург, Россия. Email: maria.mogilevich[at]gmail.com

\section{Аннотация}

Современная культурная ситуация способствует переосмыслению множества сфер человеческой деятельности, некогда казавшихся базовыми. Таким образом, критически меняется и представление об образовании, в Европейской культуре традиционно ассоциировавшееся с дисциплиной ума и воли, а, следовательно, с крайней серьёзностью. Возможность подобного подхода была тесно связана с ценностью знания, некогда представлявшейся безусловной. Однако современные медиа, сделавшие знания доступными, а формы их получения повседневными, сместили образовательную сферу с привычной позиции. Сегодня мы наблюдаем, как образование реформирует собственные цели и задачи, и какие новые методы оно привлекает, дабы продолжать оставаться неотъемлемой частью развития личности в культуре. В данной статье мы рассмотрим один из аспектов трансформации образования, а именно поиск новых мотивов обучения. Нашей целью будет характеристика образовательного потенциала техник, почерпнутых из таких областей как юмор, фантастика и игра. Все три феномена традиционно воспринимаются скорее как часть развлекательной, «несерьёзной» сферы человеческой деятельности. Мы же постараемся доказать их эффективность по отношению к новым вызовам в образовательной сфере, которые порождает эпоха новых медиа технологий.

\section{Ключевые слова}

образовательные методы; новые образовательные технологии; опыт; вовлечение; юмор; научная фантастика; геймификация; игра; мотивация; серьёзность 


\section{Introduction}

Current situation in the area of humanitarian discourse is as follows: we are accustomed to face the need not only to define new phenomena, but also to redefine the overwhelming majority of those already familiar including those that seemed basic. This can be also applied to the spheres of "serious" and "entertaining" including "laughter" in culture. The scope of this article is limited to the process of transformation of attitudes towards these areas in terms of their applying to the higher education field.

The educational practices themselves have also changed significantly before our very eyes. If a century ago the educational sphere was closely connected with the goal of storing and transferring knowledge, then in the modern situation this goal is no longer dominant. Today, knowledge is perceived as an accessible resource. And, although in practice this is not always the case, a person who has access to the Internet has the illusion that $\mathrm{s} /$ he is able to obtain the maximum of information on the matters of his/her interest at any time. Therefore, the emphases in educational activities in universities are shifting towards solving the problems of assimilating knowledge and the possibility of its application in practice (Darinskaia, \& Molodtsova, 2019, p. 8). This process significantly transforms the range of tasks coped by modern educational methods. Naturally, such vital changes cannot but affect the very image of the educational area.

Traditionally, education is one of the "serious" activities which, together with employment, are perceived as a kind of opposition to rest and entertainment. However, new challenges faced by the educational field are prompting to seek solutions in areas more associated with entertainment. In this article, we will consider three of such areas which are humor, fiction and play, in terms of their potential benefits for the new educational practices. Our goal will be to work out the reasons and to justify the active use of humorous, playful and fantastic elements in education. But before coming to the issue it is necessary once again to dwell on the tasks of education in the scope of new media technologies in more detail.

A few words should be said about the layout of the article. We will begin with identifying some of the new challenges faced by a mass university in present conditions based on an analysis of the corresponding research, and reveal their connection with the present cultural situation. Next, we'll explore the potential of using humor, fictional content, and game techniques to respond to these challenges, and demonstrate their capabilities in examples. The result will be conclusions about the applicability of humor, fiction and game in mass university, as well as the reasons why education turns to practices previously considered entertaining.

\section{Part 1. On new challenges in education}

Education is a complex and multifaceted sphere of culture. We are not trying to either comprehensively describe it, or even identify all the new trends that 
can be observed in recent decades. First of all, we would like to emphasize that it is mainly the educational structures of the mass model that fall into the field of our attention. The structures are dependent on market demands and most susceptible to changing user demands. As a result, new cultural processes affect them harder and faster.

Mass universities, in contrast to research universities, are also experiencing more strongly the already known trend of a changed attitude towards education within a market economy. They must provide educational products that students perceive in terms of the ability to meet their existing needs and stipulations. If, for example, the ideal Humboldt model of the university assumes that the educational environment will contribute to the expansion of the horizons of expectations of the participants, their internal growth, then a modern mass university finds itself in a complex ambivalent situation. It is dealing with the need to satisfy the current demand, as well as with the lingering expectation of a student to perceive his/her inner growth. It should also be mentioned that globalization processes, at whatever stage they are today, weaken the national cultural component of higher education. Mass universities are looking for universal methodologies that work for students regardless of their background (Ridings, 2009).

Let us outline a few more tendencies necessary to achieve our goal. They directly stem from the changed cultural situation associated with the integration of media technologies into human lives. One of the characteristic features of an active user of the global Internet network as we have mentioned above is the sense of accessibility of knowledge (Gritsan, 2017). The Internet allows one to find any information of any complexity in the shortest way, gain access to both world scientific libraries and interactive encyclopaedias which will guide the route of further paths of research. Moreover, acquiring knowledge in the modern world is beginning to feel like an everyday practice. Not a day goes by without an Internet user finding out something new for oneself from virtual encyclopaedias, video lectures, reviews, and podcasts. Learning something new now is an ordinary everyday process. Clearly, the quality of knowledge assimilation often leaves much to be desired with this approach. However, in the perception of the user, the value of knowledge as something that is difficult to obtain, which is the prerogative of a certain cultural stratum, certainly decreases. Moreover, the learning patterns themselves have become something very familiar and common. That is, the practice of reading, listening to lectures, and even completing assignments presents in daily activities. The number of educational and pseudo-educational products is also huge.

The consequence is a number of problems, the main one of which is that educational practices "drown" in everyday life. In the worst case, the student simply abandons them, seeing no motive to perform actions that do not bring quick results and are so little different from what happens to them all the time. In milder versions, the effectiveness of the educational process suffers. Without a point of direct application and competing daily with the mass of new incoming data, the acquired knowledge and skills are very quickly lost (Bignell, 2000). 
Through the fact that the background of students is unknown and can not be counted on in a mass university of the globalization era, neither is some external motivation coming from cultural values, the globalization processes must embed motivational schemes into the educational process. And these schemes should also be as versatile as possible.

Thus, we see that the real challenge for contemporary education is the satiety of a user of modern media technologies of various kinds with educational and knowledge-transmitting content. And, along with satiety, a modern person no longer wants to unambiguously and straightforwardly identify oneself with a particular profession or social stratum (Malkowski \& Russworm, 2017). That is why traditional motivational schemes based on the principle "any educated person (or scientist, or engineer, etc.) should know" are losing their relevance. In other words, motivational schemes that seemed to be the most universal and global are now in crisis (Tait, 2021).

In this regard, the task of motivation for learning is more urgent than ever. Paradoxically, it is solved by turning to the "not serious" side of culture. We will risk searching for such methods in areas which previously belonged to the entertainment field. In contrast to the "serious" spheres which presuppose very significant external motives, such as survival, family support, social status, etc., the "not serious" sphere entails the search for a certain self-meaning, local way of motivating the participants. This means that the challenges faced by the educational sphere recently are not new for the entertainment sphere. Moreover, it is the entertainment sphere that effectively opposes itself to everyday life which means that the methods that it uses are at the same time able to help a modern person educated by media technologies to escape from the feeling of daily routine and better perceive new experience.

We hasten to add that we will not separately consider the close to our chosen area but now a somewhat forgotten educational trend named edutainment. It assumed a more global change in attitudes towards educational practices, an emphasis on deriving pleasure from the learning process. We are interested in the potential of using mechanics drawn from the "entertainment" areas for education close to the traditional understanding. Moreover, some of the ideas and trends of edutainment have found their continuation in gamification (Jayasinghe \& Dharmaratne, 2013) which will be considered in the fourth part of this article.

Thus, the problem of motivation, involvement, and interest in education, as well as the value of the experience gained in the course of education, is a serious challenge to a modern mass university. And it is precisely the search for an answer to this challenge that interests the authors of the article. 


\section{Part 2. Humor}

As the first of the areas mechanics of which seem to be productive in responding to new educational challenges we will consider humour. This is not to say that humor has not previously been integrated into educational processes. But it was used in most cases as a kind of emotional relaxation of students, a microbreak in the information flow contributing to switching and then to a better concentration. However, a very common position was and still remains to this day is that of opposing humour to learning (Lei, Cohen, \& Russler, 2010); in its core there lies the belief that humour can interfere with a serious attitude to learning, distracting from the subject of study, and decreasing concentration. However, students' attention cannot be maintained at an even level (Kaneman, 2006); even more it is relevant in the modern situation due to the problems mentioned above.

And it is precisely in the struggle for the listener's attention that humour has another strong point. It is also worth recalling one of the oldest surviving examples of the use of humour in the educational process. Socrates also used irony in teaching (Leibowitz, 2010, p. 25). His philosophical technology which is known as the dialectical method presupposes irony as one of the components. And here it should be especially noted that humour in Plato's Dialogues read in modern times is manifested in two hypostases. First, Socrates makes irony over the interlocutor which means that he uses irony as a method of teaching demonstrating its effectiveness. Secondly, reading Plato's dialogues and realizing that Socrates is ironic over the interlocutor, we are still exposed to his irony. So the irony of Socrates is able to teach even after two and a half millennia after the events described. Socratic irony has a very rich and versatile potential. It is both a way to deeply involve the interlocutor in the discussion emotionally irritating him and a way to pose unexpected, uncomfortable questions concerning seemingly self-evident phenomena, but at the same time to provoke the interlocutor through humour which is not the unique prerogative of Socrates.

Equally, irony is not the only kind of humor, and Socratic method is not the only way to strife for the student's attention and interest. A joke, anecdote, or amusing example are great ways to make information easier to digest. Sarcasm, hyperbole, pun, provocation, funny commentary, or illustration can be great ways to grab or manipulate students' attention by revoking a variety of emotional responses.

The ability to knock the interlocutors out of familiar contexts, confound them and emotionally engage them at the same time is an inherent feature of humour. Here I would like to especially emphasize precisely the moment of emotional involvement. The nature of humour is such that it cannot leave the interlocutor indifferent. Even if the reaction is not laughter or approval but, on the contrary, indignation, aggression, or even shame, it still confronts the recipient with the need for a new critical view of the objects of humorous utterance. This makes humour 
an effective tool for problematisation, on the one hand, and, on the other, a means of raising the level of critical reflection on the issue (Ziegler, Boardman, \& Thomas, 1985). It increases our chances that the recipient will not only focus on the problem we want him to but will also be able to approach it in a non-standard way in the future.

It also is appropriate to mention the fact that many in-demand modern professions and fields of study imply the development of such competence as creativity in students. Developing creative approaches is in itself a non-trivial methodological task. And the creative sphere is especially in need of new approaches to teaching and presenting material (Corrigan, 2010). Here, humorous presentation has a very high potential for productivity, since it is humour that helps to renew the look of non-familiar things, search for the new connotations, and recheck the semantic connections of phenomena. Humour tears apart everyday life preventing it from being treated as given; and this is what effectively releases creativity. At the same time, in order to achieve its educational goals, humour does not have to be successful, i.e. to trigger positive emotions in the recipient. Alien humour which does not correspond to the contexts and culture of the one who perceives it is an excellent stimulus for understanding of the logic of a third-party, previously unfamiliar, and of alternative ways to structure reality.

As an example of the multifaceted potential of humor as a means of managing the attention and interest of the learner the use of satirical illustrations (caricatures) can serve as illustrative material for the courses of history. Thus:

- Caricature itself as a type of drawing, and even humorous one; it attracts attention, and therefore increases interest.

- Caricature complements the historical material, causing the desire to interpret and further comprehend it.

- The address to caricature makes the past era, which gave birth to it, more living and understandable, and therefore closer to the student.

- Caricature serves as an unexpected element that diverts the students' attention, refreshing their interest in the material of the lesson.

Even a small integration of humor can be effective in increasing interest and engagement in the educational process.

\section{Part 3. Fantasy}

The first glance at the term "fantastic" prompts to view it as the antipode of science, and, therefore, of the educational sphere. However, if we recall the history of the science fiction genre, we immediately notice the inconsistency of this opposition. From a historical and literary point of view, the origins of science fiction grow from philosophical and utopian works of the 16-17 centuries ("Utopia" by Thomas More or "New Atlantis" by Francis Bacon) and satirical works of 
the $17^{\text {th }}-18^{\text {th }}$ centuries ("Another World" by Cyrano de Bergerac or "Gulliver's Travels" by Jonathan Swift). On this basis, the first novel which researchers call science fiction is the gothic novel "Frankenstein, or Modern Prometheus" by Mary Shelley (Attebery \& Hollinger, 2013). Interestingly, now the second part of the title is often forgotten, although it is what marks the reason why we are dealing with science fiction. The period in which these works were created is very rich in scientific discoveries which presumably provoked creative attempts to comprehend the rapidly developing science and predict future prospects. It should be noted that thought experiments will be one of the red threads of science fiction history.

The science fiction genre is becoming popular and is rapidly gaining momentum due to the ability to develop a certain "scientific" assumption into a fullfledged image: to embody, in the form of a work of art, an idea that cannot yet be evinced in reality (teleportation, time machine, etc.). A key aspect of this genre is also the powerful and compelling image of science and technology it creates. Science fiction does not question the scientific methods described in the work, and, thanks to this, it wins the trust of readers. And, at the same time, the trust of readers in the world created in works increases the level of trust to the scientific method in reality.

Since the genre, as we mentioned above, is largely based on thought experiments, some of them, essentially, are embodied in reality which makes the genre even more popular, and convinces readers of the predictive ability of writers. "Mankind's ability to overcome the level of the empirical given is the key to interpreting many of its creations" (Tomasovicova, 2021).

Certainly, prediction based on intuition through a fictional text does not take place on the basis of a scientific method, and the theoretical calculations of science fiction most often simply simulate it. However, fantasizing on the basis of available scientific data has great educational value, if we remember that it is precisely the possibility of predictions that is one of the most powerful stimuli of scientific progress. Modern reality overflowing with knowledge and information rather serves as a sticking point for research interest. The desire to build hypotheses and forecasting seriously suffers from the presence in modern media of a huge number of different forecasts: from the weather forecast to the forecast of the cost of the grocery basket in the next half of the year (Manguel, 2015). Unlike forecasts in the media, forecasts in the works of science fiction invite for joint creative rethinking reality: they allow one to try on the diversity of the future for oneself which adds pedagogical significance to what is happening (Balakireva, 2020), while at the same time making science fiction fans more resistant to the alleged futuroshock (Toffler, 2002). No matter how events develop in the future, they are already included in the spectrum of possible expectations.

Sensitivity to the values and cultural foundations is one of the tasks of higher education in the global world. But many disciplines still require more engaging examples. Turning to science fiction can be a life-saver. Ethical disciplines are facing 
the need for poignant, engaging illustrative situations. It is often important that unnecessary connotations or topical social contexts do not distract students from the questions and problems on which the teacher wants to focus their attention.

To get a better feel for the educational potential of video games, let's analyze the game "The Talos Principle". The short plot of the game is as follows: due to an epidemic of an unknown virus, humanity was on the verge of extinction. And at the moment of realizing the imminent death, it was decided to create a technology that saved the entire array of accumulated information for the future. For this purpose, the Talos project was created. Given the impossibility of accurately predicting future events in a world where there will no longer be humanity, a group of scientists proposed a project to create artificial intelligence which could preserve the legacy of human civilization in future. Artificial intelligence was placed in an android robot which was imprisoned in a labyrinth with tasks the result of completing which would be to obtain admission to freedom, to Earth without people. The following aspect introduces additional complexity. Going through the maze involves solving a moral dilemma. The android that the gamer plays is not the first among the test subjects. When passing the labyrinth, they meet their predecessors who can be saved or left there. Passing the labyrinth is also accompanied by communication with "God" who calls himself Elohim. He tries to convince the player not to climb the tower in the center of the world, otherwise it will provoke an apocalypse. Right in the process, the game makes the player feel that what is happening to them is unreal which makes the player ultimately decide to climb the tower. In fact, at the top he is faced with another dilemma: whether to download the entire array of information accumulated by mankind onto its own carrier, or to throw it here. The decision to save information leads him to the destruction of the simulation which was a labyrinth and transfers his artificial intelligence to a real robot in a world where human civilisation died.

We can see that even this game with not the most complicated plot and mechanics plunges the player into a whole chain of thought experiments starting with the acceptance of the fact that androids endowed with artificial intelligence already exist but humanity exists no longer. And this so far fantastic assumption allows us to pose ethical questions of a new format in which the player is not bound by the already existing human ethics but is able to build a new one. At the same time a person for them is something of the past, a limiter who they creatures of the new generation are able to bypass. Or, conversely, treat them and their will with respect.

This game doesn't just serve as a topic for consideration of ethical dilemmas associated with artificial intelligence. The student gets experience in solving them independently and facing the consequences. This is also facilitated by the game mechanics of the fictional work. But the game will be discussed in the next section. 


\section{Part 4. Game}

The use of game mechanics in education and workflows has already spawned a separate discipline called "gamification". This trend seems symptomatic from the perspective of our problem. Moreover, the transfer of education to the distance format characteristic of recent years has further actualized this trend.

What is the main advantage of using game mechanics in education especially in online format? First of all, play as a type of activity is an independent closed pattern where the goal, methods of motivation, encouragement, and evaluation of results are already integrated. This is what makes the game such an attractive activity. It is transparent, voluntary, and it delivers quick, tangible results. A person entering the game sees in advance all its boundaries and perspectives which gives a sense of control over the situation. Further, the game contains a goal in itself. Having achieved this goal, a person feels satisfaction, even if it remains a pure victory in the game (Koster, 2004). And now let's remember that education, especially in the online format (offline has additional social tools to keep students active and involved), really needs an incentive for students to bring the process to completion.

The game also optimally solves the problem of cultural differences and various students' backgrounds. Here, by the way, it goes well with fantastic settings. The game creates its own internal pattern, the structure and logic of the participants' interactions with each other and with the game world. This pattern can either repeat or take into account a certain cultural source, or be completely independent not relying on existing cultural references. When play creates such a very special, culturally neutral, inner reality, it turns out to be a simple and productive way to combine representatives of different cultures or cultural layers. And it does it in as a small traumatic way as possible; because all participants are faced with the same conditions in the need of mastering unfamiliar rules and mechanisms (Hammer \& Davidson, 2017).

Due to the fact that gamification is becoming more and more popular educational trend along with successful examples of its implementation, we also receive many unsuccessful ones (Manzano-León et al., 2021). As a rule, these examples are associated with the fact that only additional mechanisms of encouragement and stimulation of players begin to be introduced into educational processes. Techniques such as rankings and achievement systems are expected to serve in and of themselves to engage in educational activities. And when the results do not meet expectations, they doubt the effectiveness of the very idea of gamification. Indeed, it would seem that even in the famous Bartle classification "achievers", that is, achievement hunters, are called the most widespread class of players (Gu \& Maher, 2014). So the introduction of additional play values should also increase the value of learning essentially but such reasoning overlooks an important aspect. Game techniques themselves are becoming more widespread in various cultural spheres. A person brought up by the modern media environment is already accus- 
tomed to ratings, awards, and achievements. Taken individually, they have little potential to stimulate anyone.

In order for gamification to work and the educational process to be as engaging as the game, it is necessary to look at the essential characteristics of the game. These characteristics are primarily associated with the creation of a certain new holistic pattern which we already mentioned above - and with the pleasure of mastering it by the trainer (Koster, 2004).

But one of the main values of the game as a type of activity is also the participant's obtaining a holistic experience based not only on the pattern of the game but also on the whole complex of its components (design, narrative, and interface). It is this holistic experience that is the focus of attention for game developers (Schell, 2015). It is this which attracts many game lovers to choose this particular hobby. And it is so often overlooked when introducing gamification into educational processes. Meanwhile, it is the work with the experience of the recipient as a whole that can be especially fruitful in education. The preliminary works in the gaming industry including the field of narrative design can help to look at the educational process as a single experience but at the same time having internal dynamics. So at the start, the students also need a period of swing and immersion; in the process bright, "climactic" events will be useful to them, and at the finish they will need some time to realize the experience gained and live through experienced emotions (Heussner, Finley, Hepler \& Lemay, 2015).

Despite the fact that theoretical understanding of game development is a fairly young field, its already existing products are obviously interesting for the educational sphere, because the focus of modern education is also the student's experience as an integral, multifaceted phenomenon. In terms of working with experiment, the games have been very successful.

The following example can be given as an illustration of the capabilities of game techniques. Here it is used as part of design training, but the mechanic has a wide range of applications. During the internship, all students are given badges and a set of star stickers. Every time a student from the group has expressed an idea or proposal that seemed creative to another, the other sticks a star on his badge. You can only evaluate other people's ideas. Thus, in the process of passing joint practice, students receive from others a certain number of stars as a third-party assessment of their own creativity. The value of this mechanic is not only in the banal challenge to get more stars. It also:

- Stimulates the attention and interest of students to each other's ideas and promotes awareness of the internal criteria for the quality of these ideas.

- Creates many opportunities of receiving external feedback and reinforcing success in the educational process, which stimulates greater awareness of actions and increases the value of what is happening. 
- Promotes within a group of students a sense of community and their own active role in the educational process.

That way this very simple game mechanic stimulates engagement, interest and activity throughout the educational process.

\section{Conclusion}

So, in this article, we have problematized the challenge to contemporary higher education consisting in increasing the motivation and interest of students. We tried to show the potential of using mechanics for this goal, taken from the spheres traditionally ranked as entertainment, not in the sense of classifying education as a means of recreation and enjoyment, but in the sense of using fundamentally non-universal, local, and situational stimuli for the student. Such stimuli can be as following: interest in deconstructing a fantastic image, overcoming a challenge according to previously known rules, or problematising irony. All these stimuli, by means of "comic" means, push to get the most real experience.

An even more important feature of these areas when applied to educational methods is the ability to build a local artificial system, such as a game or a fantastic setting within which the student will be able to master the key methods of research, analytics, and forecasting having much more accessible and visual results than if everything was happening "for real".

The once entertaining areas of humor, science fiction, and games are all about motivating and engaging students because of their ability to direct attention, arouse or refresh interest. Although the stimuli provided by the mechanics taken from the above areas seem local and situational, they contribute to the awareness of what is happening in the learning process as a holistic experience.

\section{Acknowledgements}

The reported study was funded by Russian Foundation for Basic Research (RFBR) according to the research project No 20-013-00865.

\section{References}

Attebery, B., \& Hollinger, V. (2013). Parabolas of Science Fiction. Middletown, Conn.: Wesleyan University Press,.

Bakar, F., \& Kumar, V. (2019). The use of humour in teaching and learning in higher education classrooms: Lecturers' perspectives. Journal of English for Academic Purposes, 40, 15-25. doi: 10.1016/j.jeap.2019.04.006

Balakireva, T. A. (2020). Pedagogical Function of Speculative Fiction in Digital Culture. Culture and Technology, 5(1), 12-19. doi: 10.17586/2587-800X-2020-5-1-12-19 (In Russian).

Bignell, J. (2000). Postmodern Media Culture. Edinburgh: Edinburgh University Press. 
Billah, M., Cull, M., Tibbits, G., \& He, C. (2019). The role of humour for accounting education in the 21st century. Presented at the 9th Annual International Conference on Accounting and Finance. doi: 10.5176/2251-1997_AF19.280

Corrigan, A. M. (2010). Creativity fostering, measuring and contexts. New York: Nova Science Publishers, Inc.

Darinskaia, L. A., \& Molodtsova, G. I. (2019). Modern Technologies for Teaching and Learning in SocioHumanitarian Disciplines. IGI Global.

Freud, Z. (1995). The Artist and Fantasy. Moscow: Republic. (In Russian).

Gritsan, A. V. (2017). Threats to the Transformation of Media Culture Against the Background of the Rapid Growth of Information Volumes and the Worldwide Spread of ICT. Security issues, 6(6), 19-29. doi: 10.25136/2409-7543.2017.6.24662 (In Russian).

Gu, N., \& Maher, M. L. (2014). Designing adaptive virtual worlds. ProQuest Ebook Central.

Hammer, J., \& Davidson, D. (2017). Cultural Alignment and Game-Based Learning. Educational Technology, 57(2), 31-35.

Heussner, T., Finley, T., Hepler, J., \& Lemay, A. (2015). The Game Narrative Toolbox. Routledge.

Jayasinghe, U., \& Dharmaratne, A. (2013). Game based learning vs. Gamification from the higher education students' perspective. Proceedings of 2013 IEEE International Conference on Teaching, Assessment and Learning for Engineering (TALE), 683-688. doi: 10.1109/ TALE.2013.6654524

Kaneman, D. (2006). Attention and Effort. Moscow: Sense. (In Russian).

Kapp, K. M. (2012). The Gamification of Learning and Instruction Game-Based Methods and Strategies for Training and Education. San Francisco: Pfeiffer.

Koster, R. (2004). Theory of Fun for Game Design. ProQuest Ebook Central.

Kulkarni, V. B. (2017). Overview of Reasons of Lack of Motivation in the Students of Indian Engineering Education. 2017 International Conference on Transforming Engineering Education (ICTEE), 1-5. doi: 10.1109/ICTEED.2017.8585628

Lei, S. A., Cohen, J. L., \& Russler, K. M. (2010). Humor on learning in the college classroom: Evaluating benefits and drawbacks from instructors' perspectives. Journal of Instructional Psychology, 37(4), 326-332.

Leibowitz, D. (2010). The ironic defense of Socrates: Plato's apology. Cambridge; New York: Cambridge University Press.

Manguel, A. (2015). Curiosity. New Haven: Yale University Press.

Manzano-León, A., Camacho-Lazarraga, P., Guerrero, M. A., Guerrero-Puerta, L., Aguilar-Parra, J. M., Trigueros, R., \& Alias, A. (2021). Between Level Up and Game Over: A Systematic Literature Review of Gamification in Education. Sustainability, 13(4), 2247. doi: 10.3390/su13042247

Ridings, B. (2009). The University is in Ruins. Minsk: BSU. (In Russian).

Schell, J. (2015). The Art of Game Design: A Book of Lenses, Second Edition: Vol. A. Boca Raton: CRC Press. Retrieved from http://www.crcnetbase.com/isbn/9781466598676

Tait, A. (2021). Why can I never be bothered? New Scientist, 250(3336), 41-45. doi: 10.1016/S02624079(21)00925-8

Toffler, E. (2002). Future Shock. Moscow: AST Publishing House. (In Russian). 
Tomašovičová, J. (2021). Parallels between two worlds: Literary science-fiction imagery and transhumanist visions. World Literature Studies, 13(1), 31-42. doi: 10.31577/WLS.2021.13.1.3

Ziegler, V., Boardman, G., \& Thomas, M. D. (1985). Humor, Leadership, and School Climate. The Clearing House: A Journal of Educational Strategies, Issues and Ideas, 58(8), 346-348. doi: 10.1080/00098655.1985.9955580

\section{Список литературы}

Attebery, B., \& Hollinger, V. (2013). Parabolas of Science Fiction. Middletown, Conn.: Wesleyan University Press,.

Bakar, F., \& Kumar, V. (2019). The use of humour in teaching and learning in higher education classrooms: Lecturers' perspectives. Journal of English for Academic Purposes, 40, 15-25. doi: 10.1016/j.jeap.2019.04.006

Bignell, J. (2000). Postmodern Media Culture. Edinburgh: Edinburgh University Press.

Billah, M., Cull, M., Tibbits, G., \& He, C. (2019). The role of humour for accounting education in the $21^{\text {st }}$ century. Presented at the 9th Annual International Conference on Accounting and Finance. doi: 10.5176/2251-1997_AF19.280

Corrigan, A. M. (2010). Creativity fostering, measuring and contexts. New York: Nova Science Publishers, Inc.

Darinskaia, L. A., \& Molodtsova, G. I. (2019). Modern Technologies for Teaching and Learning in SocioHumanitarian Disciplines. IGI Global.

Gu, N., \& Maher, M. L. (2014). Designing adaptive virtual worlds. ProQuest Ebook Central.

Hammer, J., \& Davidson, D. (2017). Cultural Alignment and Game-Based Learning. Educational Technology, 57(2), 31-35.

Heussner, T., Finley, T., Hepler, J., \& Lemay, A. (2015). The Game Narrative Toolbox. Routledge.

Jayasinghe, U., \& Dharmaratne, A. (2013). Game based learning vs. Gamification from the higher education students' perspective. Proceedings of 2013 IEEE International Conference on Teaching, Assessment and Learning for Engineering (TALE), 683-688. doi: 10.1109/ TALE.2013.6654524

Kapp, K. M. (2012). The Gamification of Learning and Instruction Game-Based Methods and Strategies for Training and Education. San Francisco: Pfeiffer.

Koster, R. (2004). Theory of Fun for Game Design. ProQuest Ebook Central.

Kulkarni, V. B. (2017). Overview of Reasons of Lack of Motivation in the Students of Indian Engineering Education. 2017 International Conference on Transforming Engineering Education (ICTEE), 1-5. doi: 10.1109/ICTEED.2017.8585628

Lei, S. A., Cohen, J. L., \& Russler, K. M. (2010). Humor on learning in the college classroom: Evaluating benefits and drawbacks from instructors' perspectives. Journal of Instructional Psychology, 37(4), 326-332.

Leibowitz, D. (2010). The ironic defense of Socrates: Plato's apology. Cambridge; New York: Cambridge University Press.

Manguel, A. (2015). Curiosity. New Haven: Yale University Press. 
Manzano-León, A., Camacho-Lazarraga, P., Guerrero, M. A., Guerrero-Puerta, L., Aguilar-Parra, J. M., Trigueros, R., \& Alias, A. (2021). Between Level Up and Game Over: A Systematic Literature Review of Gamification in Education. Sustainability, 13(4), 2247. doi: 10.3390/su13042247

Schell, J. (2015). The Art of Game Design: A Book of Lenses, Second Edition: Vol. A. Boca Raton: CRC Press. Retrieved from http://www.crcnetbase.com/isbn/9781466598676

Tait, A. (2021). Why can I never be bothered? New Scientist, 250(3336), 41-45. doi: 10.1016/S02624079(21)00925-8

Tomašovičová, J. (2021). Parallels between two worlds: Literary science-fiction imagery and transhumanist visions. World Literature Studies, 13(1), 31-42. doi: 10.31577/WLS.2021.13.1.3

Ziegler, V., Boardman, G., \& Thomas, M. D. (1985). Humor, Leadership, and School Climate. The Clearing House: A Journal of Educational Strategies, Issues and Ideas, 58(8), 346-348. doi: 10.1080/00098655.1985.9955580

Балакирева, Т. А. (2020). Педагогическая функция фантастики в цифровой культуре. Культура и Технологии, 5(1), 12-19. doi: 10.17586/2587-800Х-2020-5-1-12-19

Грицан, А. В. (2017). Угрозы трансформации медиа культуры на фоне стремительного роста объемов информации и всемирного распространения ИКТ. Вопросы безопасности, 6(6), 19-29. doi: 10.25136/2409-7543.2017.6.24662

Канеман, Д. (2006). Внимание и усилие. Москва: Смысл.

Ридингс, Б. (2009). Университет в руинах. Минск: БГУ.

Тоффлер, Э. (2002). Шок будущего. Москва: АСТ.

Фрейд, 3. (1995). Художник и фантазирование. Москва: Республика. 